\title{
Developmental Changes in NMDA Receptor Subunit Composition at ON and OFF Bipolar Cell Synapses onto Direction-Selective Retinal Ganglion Cells
}

\author{
Benjamin K. Stafford, ${ }^{1}$ Silvia J. H. Park, ${ }^{3}$ Kwoon Y. Wong, ${ }^{1,2}$ and Jonathan B. Demb ${ }^{3,4}$ \\ Departments of ${ }^{1}$ Ophthalmology and Visual Sciences, and ${ }^{2}$ Molecular, Cellular, and Developmental Biology, University of Michigan, Ann Arbor, Michigan \\ 48105, Departments of ${ }^{3}$ Ophthalmology and Visual Science, and ${ }^{4}$ Cellular and Molecular Physiology, Yale University, New Haven, Connecticut 06511
}

In the developing mouse retina, spontaneous and light-driven activity shapes bipolar $\rightarrow$ ganglion cell glutamatergic synapse formation, beginning around the time of eye-opening (P12-P14) and extending through the first postnatal month. During this time, glutamate release can spill outside the synaptic cleft and possibly stimulate extrasynaptic NMDA-type glutamate receptors (NMDARs) on ganglion cells. Furthermore, the role of NMDARs during development may differ between $\mathrm{ON}$ and OFF bipolar synapses as in mature retina, where ON synapses reportedly include extrasynaptic NMDARs with GluN2B subunits. To better understand the function of glutamatergic synapses during development, we made whole-cell recordings of NMDAR-mediated responses, in vitro, from two types of genetically identified direction-selective ganglion cells (dsGCs): TRHR (thyrotropin-releasing hormone receptor) and Drd4 (dopamine receptor 4). Both dsGC types responded to puffed NMDA between P7 and P28; and both types exhibited robust light-evoked NMDAR-mediated responses at P14 and P28 that were quantified by conductance analysis during nicotinic and $\mathrm{GABA}_{\mathrm{A}}$ receptor blockade. For a given cell type and at a given age, $\mathrm{ON}$ and OFF bipolar cell inputs evoked similar NMDAR-mediated responses, suggesting that ON-versus-OFF differences in mature retina do not apply to the cell types or ages studied here. At P14, puff- and light-evoked NMDAR-mediated responses in both dsGCs were partially blocked by the GluN2B antagonist ifenprodil, whereas at P28 only TRHR cells remained ifenprodilsensitive. NMDARs contribute at both $\mathrm{ON}$ and OFF bipolar cell synapses during a period of robust activity-dependent synaptic development, with declining GluN2B involvement over time in specific ganglion cell types.

Key words: activity-dependent; bipolar cell; circuit development; ganglion cell; GluN2B subunit; NMDA receptors

\section{Introduction}

Neural circuit development depends, in part, upon activitydependent mechanisms (Bleckert and Wong, 2011). In the retina, activity contributes to the formation of glutamatergic bipolar $\rightarrow$ ganglion cell synapses. Around the time of eye-opening in mice [postnatal day (P) 12-14], the retina becomes lightresponsive as bipolar cell synaptic release transitions from spontaneous to light-driven (Fisher, 1979; Tian and Copenhagen, 2001; He et al., 2011). This release is detected by both AMPA-type receptors (AMPARs) and NMDA-type receptors (NMDARs) on postsynaptic ganglion cell dendrites (Bansal et al., 2000; Wong et al., 2000; Blankenship et al., 2009; He et al., 2011). Perturbation of bipolar cell glutamate release alters the number and strength of these synapses, and may also influence the stratification of gan-

Received Oct. 18, 2013; revised Dec. 6, 2013; accepted Dec. 28, 2013.

Author contributions: B.K.S., K.Y.W., and J.B.D. designed research; B.K.S. and S.J.H.P. performed research; B.K.S. analyzed data; B.K.S. and J.B.D. wrote the paper.

This work was supported by NIH Grants EY014454, F32-EY021063, and Core Grant EY07003 to the University of Michigan, a Midwest Eye Banks research grant, and an unrestricted grant from Research to Prevent Blindness to Yale University.

The authors declare no competing financial interests.

Correspondence should be addressed to Dr. Jonathan B. Demb, 300 George Street, Suite 8100, New Haven, CT 06511. E-mail: jonathan.demb@yale.edu.

DOI:10.1523/JNEUROSCI.4461-13.2014

Copyright $\odot 2014$ the authors $\quad 0270-6474 / 14 / 341942-07 \$ 15.00 / 0$ glion cell dendrites under certain conditions (Kerschensteiner et al., 2009; Xu et al., 2010; Soto et al., 2012). Thus, activation of glutamate receptors clearly contributes to the development of retinal circuitry.

It is less clear whether these developing synapses incorporate NMDARs composed of specific subunits. NMDARs typically contain two GluN2 subunits (GluN2A-D), and during development, NMDARs containing GluN2B subunits can regulate the number and strength of developing synapses in the hippocampus (Gambrill and Barria, 2011; Gray et al., 2011; Tovar et al., 2013). In the mature retina, GluN2B-containing NMDARs are reportedly localized extrasynaptically and preferentially near ON bipolar synapses (Sagdullaev et al., 2006; Zhang and Diamond, 2009). During development, extrasynaptic receptors may be activated around eye-opening, when spontaneous activity evokes glutamate spillover (Blankenship et al., 2009). However, the subunit composition of the NMDARs activated by spontaneous activity has not been evaluated. Moreover, it is not known whether lightevoked glutamate release activates NMDARs in the developing retina, or whether activation and/or subunit composition of these receptors differs between ON and OFF bipolar synapses. Our study examined two types of genetically identified directionselective ganglion cells (dsGCs) across the first month of postnatal life to determine the role of NMDARs and GluN2B subunits in 
A
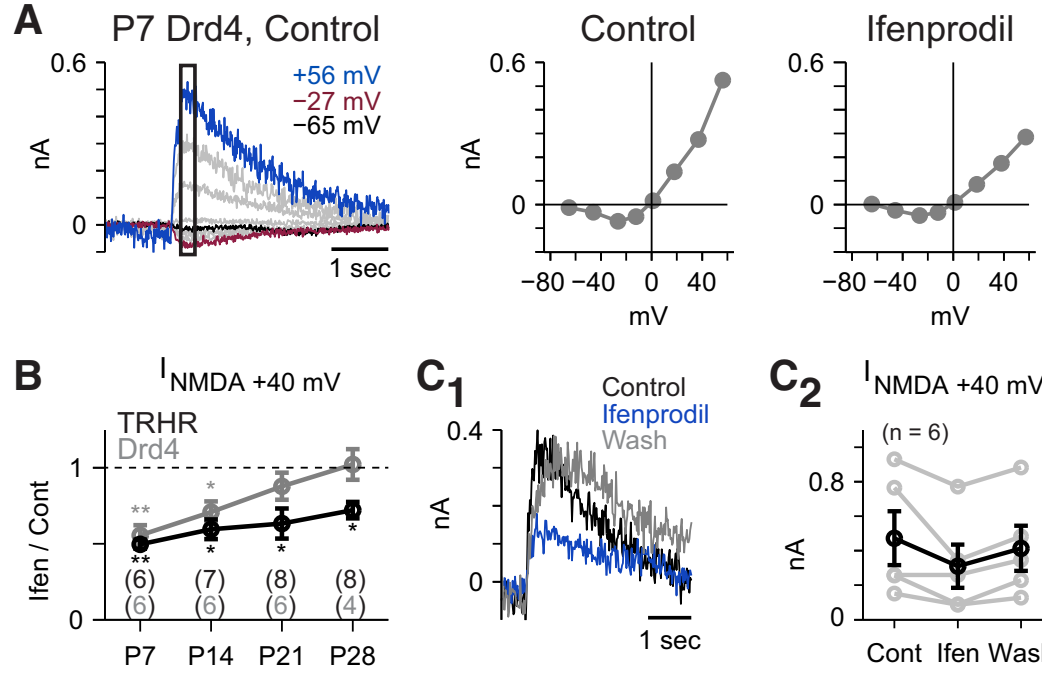

Figure 1. NMDA receptor subunit composition changes during early postnatal development. $A$, Responses to puffed NMDA (left) in a P7 Drd4 ganglion cell at a series of $V_{\text {holds. }}$. The response, averaged within the rectangle, generated a J-shaped $I-V$ plot (middle) that was reduced (right) in the presence of ifenprodil $(10 \mu \mathrm{m})$. $\boldsymbol{B}$, Ratio of the current measured at $V_{\text {hold }}$ near $+40 \mathrm{mV}$ $\left(I_{\text {NMDA }}+40 \mathrm{mV}\right)$ in the presence of ifenprodil relative to the control condition. Numbers of cells for each point are shown in parentheses. Error bars indicate \pm SEM. Ratios significantly less than one are indicated $\left({ }^{*} p<0.01,{ }^{* *} p<0.001\right)$. C1, Ifenprodil reversibly attenuated the NMDA puff response in a P7 Drd4 cell (left; $\left.V_{\text {hold }}=+55 \mathrm{mV}\right)$. C2, Ifenprodil reversibly attenuated $I_{\text {NMDA }}$ $+40 \mathrm{mV}$ in a population of P7 and P14 Drd4 and TRHR cells.

encoding glutamate release during this period of robust synaptic maturation.

\section{Materials and Methods}

Mouse strains. Mice of either sex from two strains were used: TRHR (thyrotropin-releasing hormone receptor)-GFP (Rivlin-Etzion et al., 2011) and Drd4 (dopamine receptor 4)-GFP (Huberman et al., 2009). Both mouse lines were kindly provided by Dr. Marla Feller (University of California, Berkeley, CA) and were backcrossed to C57BL/6 for $>5$ generations before establishing a colony.

Tissue preparation. All procedures conformed to the NIH guidelines for use and care of animals in research, and were approved by the University Committee on Use and Care of Animals at University of Michigan or Yale University. Procedures were similar to those described previously (Wang et al., 2011; Borghuis et al., 2013). Briefly, retinas were harvested and dissected in gassed $\left(95 \% \mathrm{O}_{2}\right.$ and $\left.5 \% \mathrm{CO}_{2}\right)$ Ames medium (SigmaAldrich) under infrared illumination, and cut along the dorsal-ventral axis (Wei et al., 2010; Wang et al., 2011). For NMDA application experiments, both dorsal and ventral pieces were used; for light-stimulation, only ventral pieces were used.

Electrophysiology. A piece of retina was placed in a chamber on an upright microscope and superfused $(\sim 5 \mathrm{ml} / \mathrm{min})$ with gassed $\left(95 \% \mathrm{O}_{2}\right.$ and $5 \% \mathrm{CO}_{2}$ ) Ames medium heated to $33-35^{\circ} \mathrm{C}$, as described previously (Wang et al., 2011; Borghuis et al., 2013). The retina and electrode were visualized at $60 \times(0.9$ or $1.0 \mathrm{NA})$ under IR illumination. In some experiments, green-fluorescent-protein-expressing $(\mathrm{GFP}+)$ ganglion cells were visualized by attenuated mercury light passed through a GFP dichroic mirror (Chroma). A GFP+ soma was localized and targeted for recording under IR illumination. In other experiments, GFP + cells were targeted by two-photon imaging, as described previously (Borghuis et al., 2013).

Cells were recorded with borosilicate glass pipettes (4-6 M $\Omega$ ) filled with intracellular solution containing the following (in mM): 110 Csmethanesulphonate, 5 TEA-Cl, 10 HEPES, 3 NaCl, 10 BAPTA, 2 QX314-Cl, 2-4 ATP- $\mathrm{Mg}^{2+}$, and 0.3-0.4 GTP-Na, titrated to $\mathrm{pH} 7.3$. Chemicals were purchased from Sigma-Aldrich, Invitrogen, or Tocris Bioscience. Voltage-clamp recordings were performed as described previously (Manookin et al., 2010). For voltage-step protocols, initial $V_{\text {hold }}$ $(-100$ to $-75 \mathrm{mV})$ was stepped up every $8 \mathrm{~s}(10-20 \mathrm{mV}$ increments $)$ followed by a return to the initial level.

Puff-evoked NMDA response. Responses to puffed NMDA were measured with synaptic transmission strongly attenuated by bath applying the following (in $\mu \mathrm{M}$ ): the L-type $\mathrm{Ca}^{2+}$ channel blocker isradipine (30); antagonists to

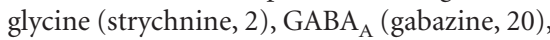
and $\mathrm{AMPA} /$ kainate $(\mathrm{CNQX}, 100)$ receptors; and the NMDAR coagonist D-serine (200). A puffer pipette (3-5 M $\Omega$ ) containing NMDA (10 $\mathrm{mm})$ dissolved in Ames medium with D-serine $(200 \mu \mathrm{M})$ and isradipine $(30 \mu \mathrm{M})$ was connected to a Pico-spritzer (Parker Hannafin) and positioned near the soma. NMDA was applied via $10-30 \mathrm{~ms}$ puffs at $10-15$ psi.

Light stimulation. The retina was stimulated by the combined output of 12 UV LEDs (peak $365 \mathrm{~nm}$, LZC-70U600, LEDEngin). Flashes were triggered by pClamp 9 software, and intensity was controlled by a pulse generator (WPI) via a custom noninverting voltage-tocurrent converter using an operational amplifier. In most experiments, stimuli $(2 \mathrm{~mm}$ diameter) were $1 \mathrm{~s}$ flashes from a dark background at $\sim 10^{4}$ photoisomerizations $\left(R^{*}\right) / \mathrm{S}$ cone/s (assuming a $1 \mu \mathrm{m}^{2}$ cone collecting area; Wang et al., 2011) presented through a $4 \times$ objective $(0.13 \mathrm{NA})$. In some experiments, intensity was attenuated (to $2-5 \times 10^{3} R^{\star} / \mathrm{S}$-cone/s) to reduce the response at $V_{\text {hold }}=+40 \mathrm{mV}$ by $\sim 50 \%$. In other experiments, contrast-modulated UV spots (peak, 395 $\mathrm{nm}$; mean luminance, $\sim 0.5 \times 10^{4}$ photoisomerizations/S-cone/s) were presented through the condenser, as described previously (Borghuis et al., 2013).

Assessing the impact of GFP epifluorescence on UV light responses. Epifluorescence for identifying GFP + dsGCs did not substantially bleach $\mathrm{S}$-cone photopigment. GFP-negative ON $\alpha$ cells $(n=3)$ targeted under IR illumination were recorded in ventral retina (van Wyk et al., 2009; Estevez et al., 2012), where cones express primarily S-opsin with peak sensitivity at $\sim 360 \mathrm{~nm}$ (Jacobs et al., 1991; Wang et al., 2011). These cones should be relatively insensitive to the GFP excitation wavelength $(\sim 488 \mathrm{~nm})$. ON $\alpha$ cell conductance (i.e., slope of the linear currentvoltage relationship) to a $365 \mathrm{~nm}$ UV stimulus was similar before (44 \pm $10 \mathrm{nS})$ and after either one $(43 \pm 8 \mathrm{nS})$ or $2 \min (43 \pm 6 \mathrm{nS})$ of $488 \mathrm{~nm}$ exposure. In typical dsGC recordings, we exposed ventral tissue to $<30$ s of $488 \mathrm{~nm}$ light, which should minimally impact cone-mediated responses.

Analysis. Responses were analyzed using custom MATLAB routines (version 7.10). A conductance analysis was performed on leak-subtracted responses, as described previously (Manookin et al., 2010). Input resistance for representative samples was $207 \pm 17 \mathrm{M} \Omega$ (TRHR; $n=39)$ and $226 \pm 16 \mathrm{M} \Omega(\operatorname{Drd} 4 ; n=28)$, and the uncompensated series resistance was $16 \pm 1 \mathrm{M} \Omega$. Current-voltage $(I-V)$ relationships were modeled as the weighted sum of three ligand-gated currents $\left(I_{\text {ligand }}\right)$ mediated by AMPA, NMDA, and GABA/glycine receptors (least-squares fit; Manookin et al., 2010):

$$
I_{\text {total }}=W_{\mathrm{AMPA}} \times I_{\mathrm{AMPA}}+W_{\mathrm{NMDA}} \times I_{\mathrm{NMDA}}+W_{\mathrm{GABA} / \text { lycine }} \times I_{\mathrm{GABA} / \text { glycine }}
$$

The weights estimate the ligand-gated conductances that combine to generate the measured $I-V$ relationship. The NMDA weights, which are strongly voltage-dependent, represent the conductance at $-60 \mathrm{mV}$ (i.e., around the resting potential).

For the data in Figure 3 (ON or OFF responses at P14 or P28), the AMPAR- and NMDAR-mediated conductances measured were each similar between the two cell types, and there was no evidence for bimodality between cell types ( $p>0.1$; Hartigan's dip test); data from the two types were therefore combined. Statistical comparisons were performed using one-sample, two-tailed Student's $t$ tests. Results are reported as mean \pm SEM. 

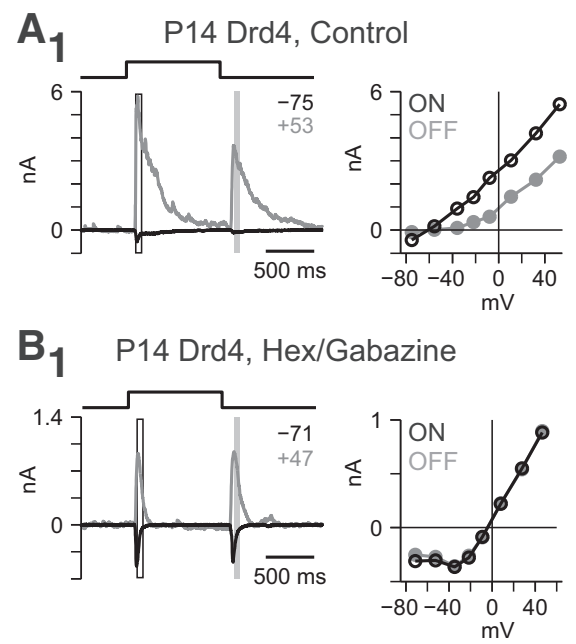

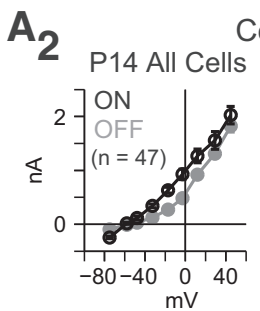

Control

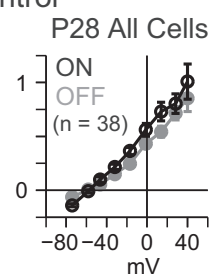

$\mathrm{B}_{2}$

Hex/Gabazine

P14 All Cells P28 All Cells
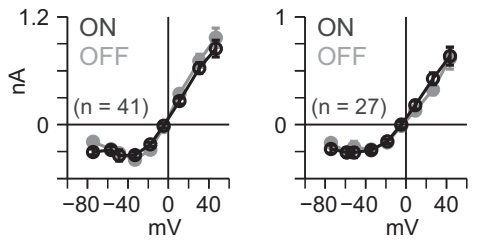

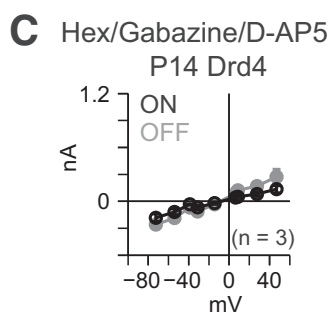

D

Hex/Gabazine/L-AP4 P14 TRHR

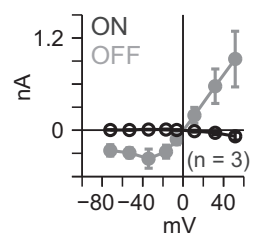

Figure 2. Light-evoked responses are dominated by inhibition. A1, A P14 Drd4 ganglion cell response to $1 \mathrm{~s}$ of UV light ( $365 \mathrm{~nm}, 2 \mathrm{~mm}$ diameter). Here and elsewhere, synaptic currents are shown at the two indicated $V_{\text {holds }}$ (in $\mathrm{mV}$; left) and current responses averaged within the white (light- $0 \mathrm{~N}$ ) and gray (light- $0 \mathrm{FF}$ ) rectangles are plotted versus $V_{\text {hold }}$ (right). $I-V$ plots were linear and reversed near $E_{\mathrm{Cl}}(-67 \mathrm{mV})$. A2, Averaged $I-V$ plots for ON and OFF responses for a combined population of Drd4 and TRHR cells at P14 and P28. Error bars indicate \pm SEM. B1, Same format as A1 in the presence of hexamethonium $(100 \mu \mathrm{M})$ and gabazine $(20 \mu \mathrm{M}) . I-V$ plot was J-shaped and reversed near $E_{\text {cation }}(0 \mathrm{mV})$. B2, Population averages for the response in B1. C, Population averages when D-AP5 $(100 \mu \mathrm{M})$ was added to hexamethonium and gabazine, blocking the J-shaped I-V relationship. D, Population averages when L-AP4 (50 $\mu \mathrm{M})$ was added to hexamethonium and gabazine, blocking the $0 \mathrm{~N}$ response selectively.

\section{Results \\ NMDA receptor subunit composition changes during early postnatal development}

Puffing NMDA evoked responses in GFP + dsGCs in both TRHR and Drd4 mice at four ages (P7, P14, P21, P28). These responses reflected opening of NMDA channels, because synaptic transmission and multiple receptors (AMPA/kainate, $\mathrm{GABA}_{\mathrm{A}}$, and glycine) were blocked (see Materials and Methods); and the $I-V$ relationship showed the characteristic J-shape of an NMDARmediated response (Traynelis et al., 2010). In both cell types, the GluN2B antagonist ifenprodil ( $10 \mu \mathrm{M}$; Fig. $1 A$ ) suppressed $\sim 50 \%$ of the response at $\mathrm{P} 7$, as quantified by the ifenprodil:control response ratio measured at $V_{\text {hold }}$ near $+40 \mathrm{mV}\left(\mathrm{I}_{\mathrm{NMDA}}+40 \mathrm{mV}\right)$ where NMDAR conductance is maximal (Fig. $1 B$ ). During development, ifenprodil's effect diminished, and differences between the cell types emerged. In Drd4 cells, the ifenprodil:control response ratio was significantly $<1$ at $\mathrm{P} 7(0.55 \pm 0.06 ; p<0.001)$ and P14 (0.71 $\pm 0.07 ; p<0.01)$, but not at P21 (0.83 $\pm 0.10 ; p>$ $0.2)$ or P28 (1.03 $\pm 0.08 ; p>0.2)$. In TRHR cells, the ratio was $<1$ at all four ages: $\mathrm{P} 7(0.47 \pm 0.03 ; p<0.001), \mathrm{P} 14(0.58 \pm 0.08 ; p<$ $0.005), \mathrm{P} 21(0.63 \pm 0.09 ; p<0.01)$, and P28 (0.72 $\pm 0.05 ; p<$ 0.005 ). Ifenprodil's effect could be reversed upon washout (Fig. $1 C 1, C 2)$. These results suggest that Drd4 and TRHR dsGCs differ in GluN2B subunit expression by P28.

\section{Glutamatergic inputs onto dsGCs could be isolated pharmacologically}

Puff-evoked NMDA activates all membrane-bound receptors, including nonsynaptic receptors distant from release sites; whereas light-evoked glutamate release specifically activates synaptic, and possibly, extrasynaptic receptors near release sites (Zhang and Diamond, 2009). UV light responses were studied in targeted GFP + dsGCs in the ventral retina (see Materials and Methods). We tested whether NMDARs were activated by lightevoked glutamate release at P14 and P28, which spans much of the period of bipolar $\rightarrow$ ganglion cell synapse formation.

In a P14 Drd 4 cell, a UV flash (1 s; 2 mm diameter) evoked robust responses at light-onset and light-offset that were domi- nated by inhibition, resulting in linear $I-V$ relationships that reversed near the chloride equilibrium potential $\left(E_{\mathrm{Cl}} ;-67 \mathrm{mV}\right.$; Fig. $2 A)$. Data from the two cell types were qualitatively similar and were combined to generate averaged $I-V$ plots at P14 and P28 (Fig. 2A). The large inhibitory input obscured the relatively small excitatory input (Poleg-Polsky and Diamond, 2011).

Glutamatergic excitatory responses were subsequently isolated by applying antagonists to nictotinic acetylcholine (hexamethonium, $100 \mu \mathrm{M}$ ) and $\mathrm{GABA}_{\mathrm{A}}$ (gabazine, $20 \mu \mathrm{M}$ ) receptors. Transient responses at light-onset and light-offset (Fig. 2B) showed J-shaped $I-V$ relationships reversing near $E_{\text {cation }}(0 \mathrm{mV}$; Fig. 2B). Data from the two cell types were qualitatively similar and were combined to generate averaged $I-V$ plots at P14 and P28; a J-shaped $I-V$ relationship was apparent at both ages (Fig. $2 B)$. The J-shape was blocked by the NMDAR antagonist D-AP5 (100 $\mu \mathrm{M}$; Fig. 2C; Manookin et al., 2010), and the ON response was blocked by the group III mGluR agonist L-AP4 (50 $\mu \mathrm{M}$; Fig. $2 D$ ), which suppresses ON bipolar cells. Thus, ON and OFF bipolar release onto NMDARs could be individually evaluated by light-ON and light-OFF responses in the presence of nicotinic and $\mathrm{GABA}_{\mathrm{A}}$ receptor antagonists.

\section{NMDARs on ON and OFF dsGC dendrites can be activated by} light-evoked glutamate release in dsGCs

Light responses were modeled as the weighted sum of three basis functions (Fig. 3A; see Materials and Methods) where the weights describe each receptor's conductance (Manookin et al., 2010). The AMPAR basis function was assumed to be linear and reverse at $0 \mathrm{mV}$. The NMDAR basis function was derived from puffevoked NMDA responses (Fig. 1), and the inhibitory (GABA/ glycine) receptor basis function was derived from the light-ON response under control conditions, which was dominated by inhibition (Fig. 2). Population analysis was performed on normalized conductances, and fits were converted to $I-V$ basis functions (Fig. 3B) as described previously (Manookin et al., 2010).

At P14, TRHR cell responses showed J-shaped $I-V$ relationships that were well fit by the basis functions (Fig. 3C). Data from the two cell types showed similar patterns of excitatory conduc- 
A

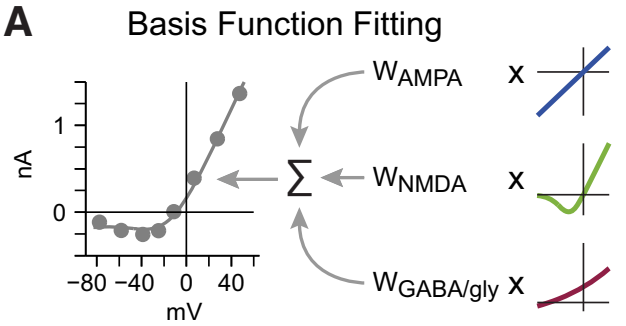

C

P14 TRHR
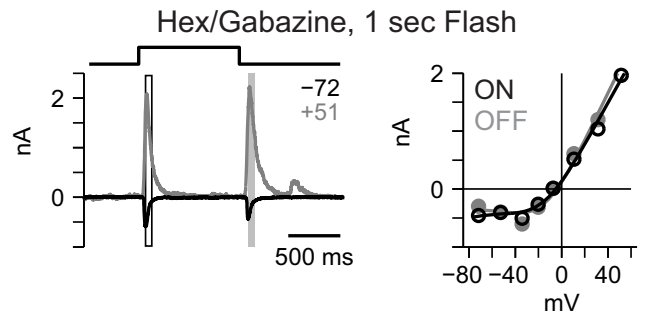

P14 TRHR

D Curare/Gabazine, $1 \mathrm{~Hz}$ Squarewave
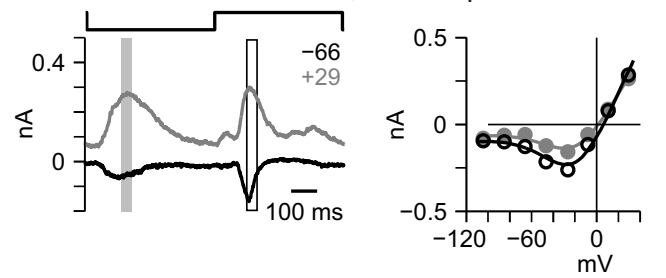

$\mathrm{E}_{1}$

Flash P14 Drd4 \& TRHR High Intensity Low Intensity

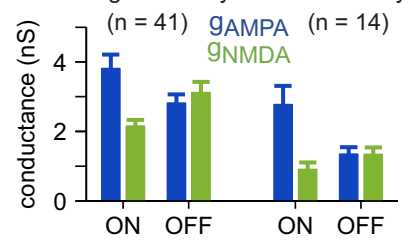

B

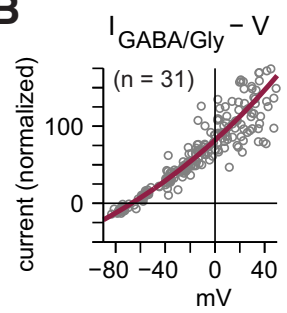

$\mathbf{F}$

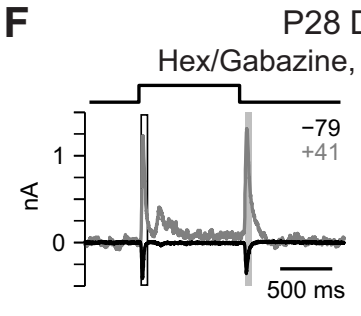

P28 Drd4

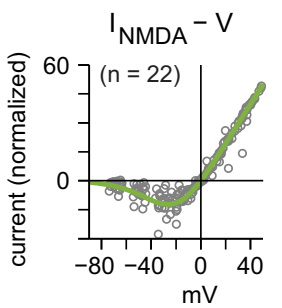

G
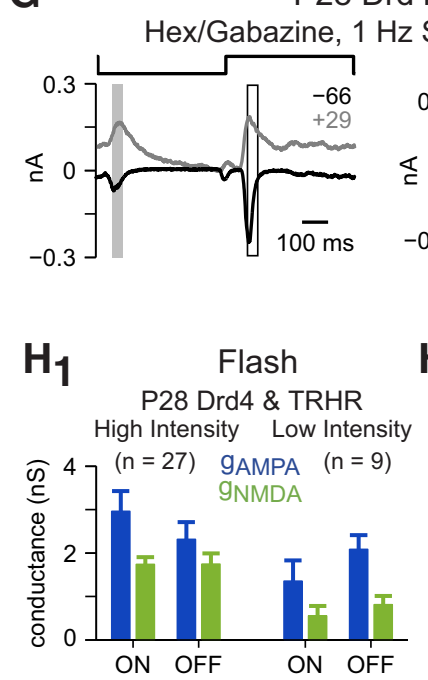

P28 Drd4
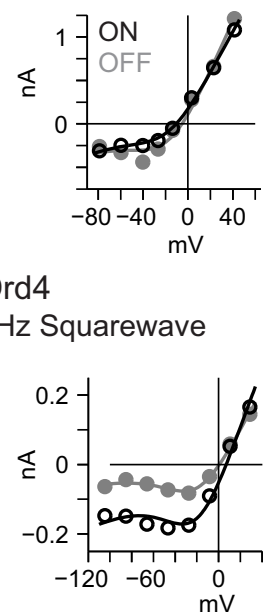

$\mathrm{H}_{2}$ Squarewave P28 Drd4 \& TRHR

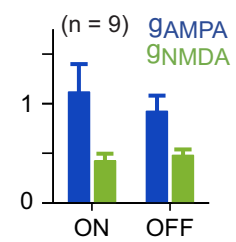

Figure 3. NMDARs are activated by light-evoked glutamate release at P14 and P28 in both Drd4 and TRHR cells. $A$, Light-evoked responses in the presence of nicotinic and GABA $A_{A}$ receptor block were fit (line) by the weighted sum of three basis functions: AMPAR, NMDAR, and inhibitory (GABA/glycine) receptors. $B$, Population fit of Drd4 light-onset response (left; as in Fig. $2 A$ ) and NMDA puff-evoked response (right; as in Fig. $1 A$ ) determined the GABA/Glycine and NMDA receptor basis functions. C, Synaptic currents and $I-V$ plots from a P14 TRHR cell in response to $1 \mathrm{~s}$ of UV light (2 $\mathrm{mm}$ diameter) in the presence of hexamethonium (100 $\mu \mathrm{M})$ and gabazine $(20 \mu \mathrm{M})$. $\boldsymbol{D}$, Same format as $\boldsymbol{C}$ in the presence of curare (50 $\mu \mathrm{m})$ and gabazine (20 $\mu \mathrm{m})$. The cell was targeted using two-photon imaging, and the stimulus was a 100\% contrast-reversing spot ( $0.17 \mathrm{~mm}$ diameter) with a background at the mean luminance. E1, $I-V$ plots from P14 Drd4 and TRHR cells were fit with basis functions (smooth curves in $C, D$ ) to determine the underlying ligand-gated conductances. ON and OFF responses showed significant AMPAR-and NMDAR-mediated conductances $\left(g_{\text {AMPA }} ; g_{\text {NMDA }}\right.$ ) at high (left) and low-intensites (right). Error bars indicate \pm SEM. E2, Same as in $\boldsymbol{E 1}$ for $100 \%$ contrast square-wave stimuli. $\boldsymbol{F}$ - $\boldsymbol{H}$, Same format as $\boldsymbol{C}-\boldsymbol{E}$ for P28 cells, with a Drd4 example cell (F, G).

tance and were combined (see Materials and Methods; data from individual cell types are shown in Fig. 4). Both cell types showed significant AMPAR- and NMDAR-mediated conductances at light-onset and light-offset ( $p<0.001$ in each case; Fig. 3E). A low-intensity flash that reduced responses by approximately twofold (see Materials and Methods) also generated significant AMPAR- and NMDAR-mediated conductances $(p<0.001$ in each case; Fig. $3 E$ ). Here, and in all subsequent experiments using hexamethonium and gabazine, the inhibitory conductance was not significantly greater than zero for either response in either cell type (data not shown; $p>0.1$ in all cases). To determine whether spatially restricted stimuli also elicited NMDAR-mediated conductances, GFP + cells were targeted by two-photon microscopy, and a smaller stimulus $(0.17 \mathrm{~mm}$ diameter; $100 \%$ contrast $)$ was presented against a uniform background at mean luminance (see Materials and Methods). In some cases, the nicotinic antagonist curare $(50 \mu \mathrm{M})$ replaced hexamethonium. This stimulus generated smaller responses overall, but still showed significant AMPAR- and NMDAR-mediated conductances at both light-onset and lightoffset in both cell types ( $p<0.001$ in each case; Fig. $3 D, E)$. Thus, at $\mathrm{P} 14$, light-evoked glutamate release activates NMDARs at ON and OFF bipolar terminals in Drd4 and TRHR cells.

Recordings at $\mathrm{P} 28$ showed similar results. The UV flash generated significant AMPAR- and NMDAR-mediated components at lightonset and light-offset in both cell types at both stimulus intensities $(p<0.05$ in each case; Fig. $3 F, H)$, as did the contrast-reversing spot $(p<0.001$ in each case; Fig. $3 G, H)$. Thus, at P14 and P28, light-ON and light-OFF responses reliably activate NMDARs.

NMDARs activated by light-evoked glutamate release contain GluN2B subunits at P14 but show cell-type-specific composition at $\mathbf{P} 28$

At P14, the UV flash response showed sensitivity to ifenprodil, demonstrating a GluN2B subunit contribution (Fig. $4 A$ ). We 
A
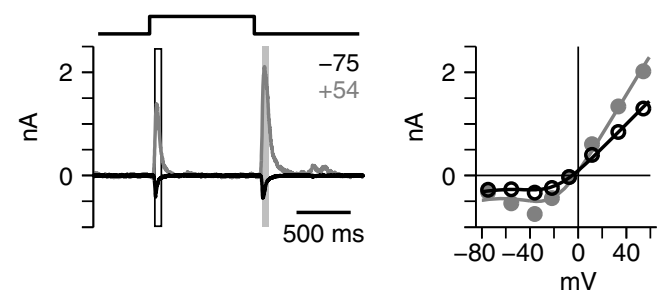

P14 Drd4, Hex/Gabazine/lfenprodil
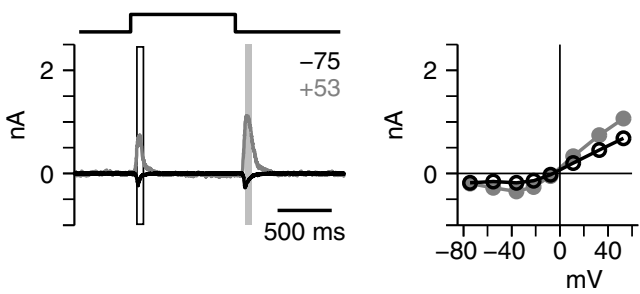

B
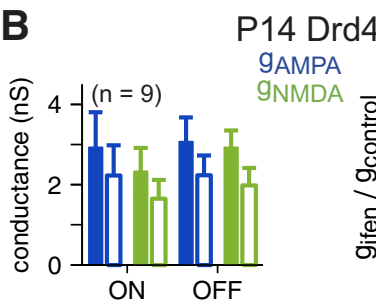

D

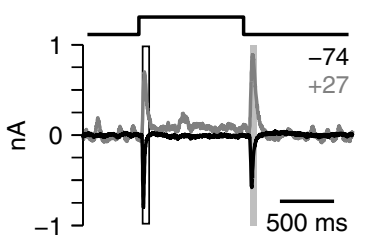

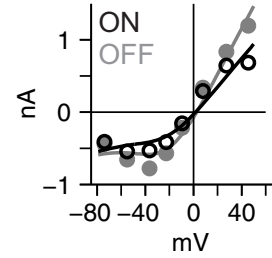

C
P14 TRHR
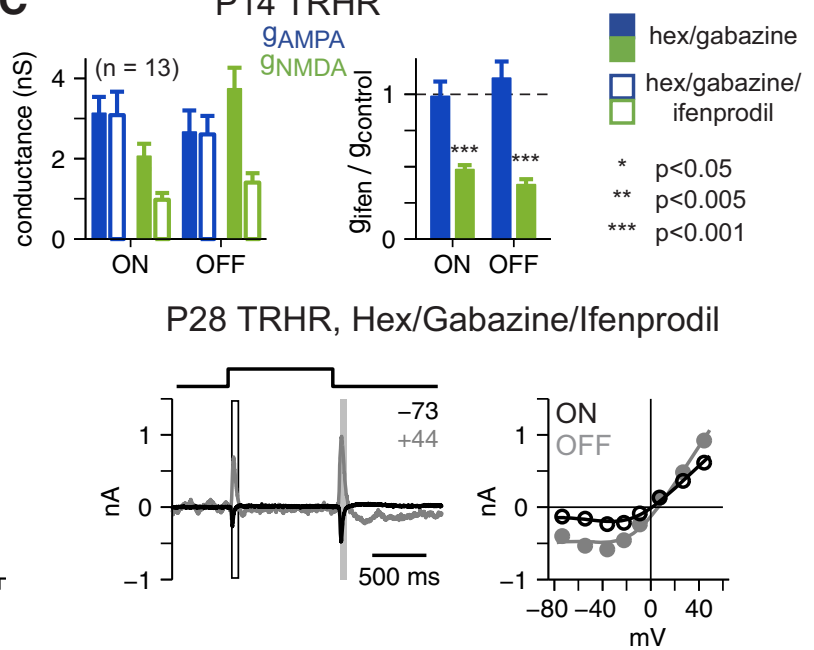

E

\section{$\mathbf{F}_{\mathbf{1}}$}

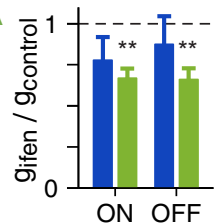

ON OFF
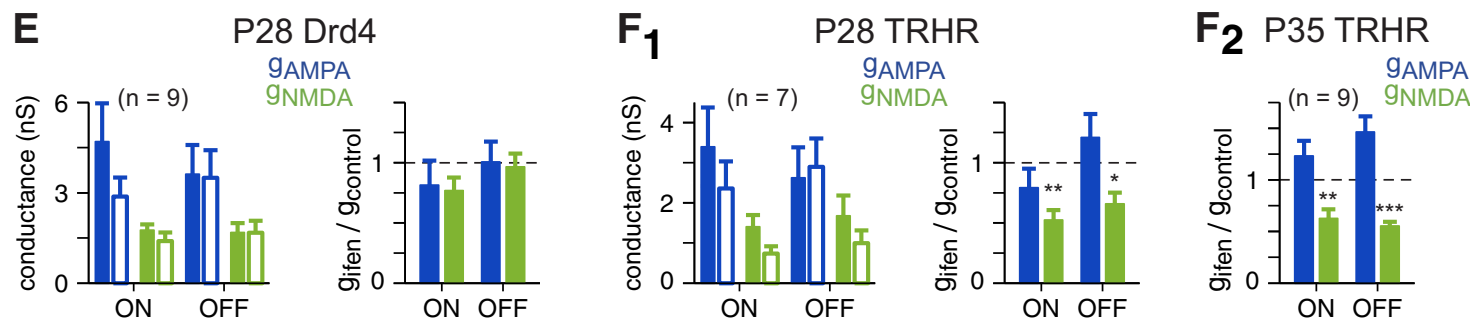

Figure 4. NMDARs activated by light-evoked glutamate release contain GluN2B subunits at P14 but show cell-type differences at P28. $A$, Synaptic currents and $I-V$ plots in a P14 Drd4 cell in response to $1 \mathrm{~s}$ of UV light ( $2 \mathrm{~mm}$ diameter) in the presence of hexamethonium $(100 \mu \mathrm{M})$ and gabazine ( $20 \mu \mathrm{m}$; left). Adding ifenprodil (10 $\mu \mathrm{m}$, right) reduced the response. $\boldsymbol{B}$, Conductance analysis of P14 Drd4 cells in the absence and presence of ifenprodil $(10 \mu \mathrm{M})$ and the ratio of the conductance in ifenprodil relative to control ( $\left.g_{\text {ifen }} / g_{\text {control }}\right)$. Error bars indicate \pm SEM. C, Same format as in B for P14 TRHR cells. D-F, Same format as $\boldsymbol{A}-\boldsymbol{C}$. At P28, TRHR cells $(\boldsymbol{F}$ 1) but not Drd4 cells $(\boldsymbol{E})$, showed persisting sensitivity to ifenprodil, and this effect on TRHR cells continued at P35 (F2).

quantified ifenprodil's effect by the ratio of the fitted conductances in ifenprodil relative to control conditions (i.e., hexamethonium and gabazine only). For Drd4 and TRHR cells, ifenprodil significantly reduced NMDAR ratios below one $(p<$ 0.005 in each case), whereas the AMPAR ratios were not affected $(p>0.1$; Fig. $4 B, C)$. Thus, GluN2B-containing NMDARs were activated by light-evoked glutamate release at ON and OFF synapses onto Drd4 and TRHR dsGCs.

The same experiment at P28 showed differences between the cell types. For Drd4 cells, AMPAR and NMDAR ratios were unaffected by ifenprodil ( $p>0.1$ in all cases; Fig. $4 E$ ). In TRHR cells, ifenprodil significantly reduced the NMDAR ratios $(p<0.05$ in each case), but not the AMPAR ratios ( $p>0.2$; Fig. $4 D, F)$. To test whether the TRHR cells were simply delayed in their loss of ifenprodil sensitivity, we performed experiments at P35. Ifenprodil continued to reduce the NMDAR ratios $(p<0.005$ in each case), but not the AMPAR ratios $(p>0.9$; Fig. $4 F)$ at P35. Thus, by P28, NMDARs on TRHR cells continue to incorporate GluN2B subunits at $\mathrm{ON}$ and $\mathrm{OFF}$ bipolar synapses, whereas those of Drd4 cells do not.

\section{Discussion}

Here, we evaluated functional NMDAR-mediated responses in two types of genetically identified dsGCs during the first postnatal month (Huberman et al., 2009; Rivlin-Etzion et al., 2011). Our main findings are as follows: (1) GluN2B-containing NMDARs are activated by light-evoked glutamate release at synaptic and possibly extrasynaptic locations on $\mathrm{ON}$ and OFF layer dendrites during a period of bipolar $\rightarrow$ ganglion cell synapse formation (Figs. 2-4), and (2) GluN2B subunits are developmentally downregulated from functional NMDARs in a cell-type-specific fashion; through P14, both cell types express GluN2B-containing NMDARs, whereas at P28, only TRHR cells continued to express GluN2B subunits (Figs. 1, 4).

The functional downregulation of GluN2B subunits supports anatomical studies in rodent suggesting that ganglion cell GluN2B expression peaks before P21 (Hartveit et al., 1994; Watanabe et al., 1994; but see Guenther et al., 2004). Further, spontaneous glutamate release activates NMDARs around eyeopening (Bansal et al., 2000; Wong et al., 2000; Blankenship et al., 
2009). However, it was not known whether GluN2B subunits incorporate into functional NMDARs that are activated by spontaneous activity. Our data show, by P7, functional GluN2Bcontaining NMDARs on ganglion cells that could be activated by spontaneous release before eye opening.

NMDARs would apparently contribute to light-evoked responses in vivo. Direction selectivity is present by P11 (Chen et al., 2009), and preferred-direction motion depolarizes the membrane potential by $\sim 10-20 \mathrm{mV}$ to drive spiking (Chen et al., 2009; Dhande et al., 2013). We found some NMDAR-mediated conductance at rest $(\sim-65$ to $-60 \mathrm{mV})$, which should grow larger with depolarization toward spike threshold (Fig. 1). Thus, it is likely that dsGCs commonly experience light-evoked glutamate release that generates sufficient depolarization to activate NMDARs on their dendrites.

Our data suggest that light stimulation evokes release onto synaptic NMDARs and possibly onto extrasynaptic NMDARs as well. Bright UV flashes evoked a strong inhibitory conductance that coincided with excitation (Fig. 2), and prevented quantification of the excitatory conductance. Glutamate conductance was instead measured under nicotinic/GABA ${ }_{\mathrm{A}}$ receptor blockade (Fig. 3), which may have caused or augmented glutamate spillover. Two findings suggested that spillover is not essential to activate NMDARs. First, NMDARs contributed to weak responses to dim or small stimuli (Fig. 3), which likely limited spillover. Second, ifenprodil-insensitive, presumed GluN2A subunit contributions to the light-evoked responses suggested that some NMDARs reside at both ON and OFF bipolar synapses (Zhang and Diamond, 2009). The additional contribution of extrasynaptic NMDARs to light-evoked responses during development deserves further study.

In the retina, bipolar cell $\rightarrow$ ganglion cell synapse formation peaks between P14 and P28 (Morgan et al., 2008, 2011; Kerschensteiner et al., 2009; Soto et al., 2011). GluN2B subunits could play a role in controlling synapse number during this period, although the duration of this role would apparently vary by cell type (Fig. 4). Further, we found no evidence for differential localization of GluN2B subunits at ON and OFF synapses, as suggested in mature retina (Zhang and Diamond, 2009). Thus, GluN2B subunits may regulate the development of glutamate receptor density, according to models proposed in other systems (Gambrill and Barria, 2011; Gray et al., 2011), but their precise role in retinal synaptic development requires further investigation.

Drd4 and TRHR dsGCs both respond preferentially to the same (posterior) direction of motion, and therefore, appeared to be the same dsGC type. However, their axonal projection patterns, and directional tuning properties differ, suggesting that they are, in fact, distinct types (Rivlin-Etzion et al., 2011). This interpretation is supported by our data showing different GluN2B subunit expression at P28.

\section{References}

Bansal A, Singer JH, Hwang BJ, Xu W, Beaudet A, Feller MB (2000) Mice lacking specific nicotinic acetylcholine receptor subunits exhibit dramatically altered spontaneous activity patterns and reveal a limited role for retinal waves in forming $\mathrm{ON}$ and OFF circuits in the inner retina. J Neurosci 20:7672-7681. Medline

Blankenship AG, Ford KJ, Johnson J, Seal RP, Edwards RH, Copenhagen DR, Feller MB (2009) Synaptic and extrasynaptic factors governing glutamatergic retinal waves. Neuron 62:230-241. CrossRef Medline

Bleckert A, Wong RO (2011) Identifying roles for neurotransmission in circuit assembly: insights gained from multiple model systems and experimental approaches. Bioessays 33:61-72. CrossRef Medline

Borghuis BG, Marvin JS, Looger LL, Demb JB (2013) Two-photon imaging of nonlinear glutamate release dynamics at bipolar cell synapses in the mouse retina. J Neurosci 33:10972-10985. CrossRef Medline

Chen M, Weng S, Deng Q, Xu Z, He S (2009) Physiological properties of direction-selective ganglion cells in early postnatal and adult mouse retina. J Physiol 587:819-828. CrossRef Medline

Dhande OS, Estevez ME, Quattrochi LE, El-Danaf RN, Nguyen PL, Berson DM, Huberman AD (2013) Genetic dissection of retinal inputs to brainstem nuclei controlling image stabilization. J Neurosci 33:17797-17813. CrossRef Medline

Estevez ME, Fogerson PM, Ilardi MC, Borghuis BG, Chan E, Weng S, Auferkorte ON, Demb JB, Berson DM (2012) Form and function of the M4 cell, an intrinsically photosensitive retinal ganglion cell type contributing to geniculocortical vision. J Neurosci 32:13608-13620. CrossRef Medline

Fisher LJ (1979) Development of synaptic arrays in the inner plexiform layer of neonatal mouse retina. J Comp Neurol 187:359-372. CrossRef Medline

Gambrill AC, Barria A (2011) NMDA receptor subunit composition controls synaptogenesis and synapse stabilization. Proc Natl Acad Sci U S A 108:5855-5860. CrossRef Medline

Gray JA, Shi Y, Usui H, During MJ, Sakimura K, Nicoll RA (2011) Distinct modes of AMPA receptor suppression at developing synapses by GluN2A and GluN2B: single-cell NMDA receptor subunit deletion in vivo. Neuron 71:1085-1101. CrossRef Medline

Guenther E, Schmid S, Wheeler-Schilling T, Albach G, Gründer T, Fauser S, Kohler K (2004) Developmental plasticity of NMDA receptor function in the retina and the influence of light. FASEB J 18:1433-1435. CrossRef Medline

Hartveit E, Brandstätter JH, Sassoè-Pognetto M, Laurie DJ, Seeburg PH, Wässle H (1994) Localization and developmental expression of the NMDA receptor subunit NR2A in the mammalian retina. J Comp Neurol 348:570-582. CrossRef Medline

He Q, Wang P, Tian N (2011) Light-evoked synaptic activity of retinal ganglion and amacrine cells is regulated in developing mouse retina. Eur J Neurosci 33:36-48. CrossRef Medline

Huberman AD, Wei W, Elstrott J, Stafford BK, Feller MB, Barres BA (2009) Genetic identification of an on-off direction-selective retinal ganglion cell subtype reveals layer-specific subcortical map of posterior motion. Neuron 62:327-334. CrossRef Medline

Jacobs GH, Neitz J, Deegan JF 2nd (1991) Retinal receptors in rodents maximally sensitive to ultraviolet light. Nature 353:655-656. CrossRef Medline

Kerschensteiner D, Morgan JL, Parker ED, Lewis RM, Wong RO (2009) Neurotransmission selectively regulates synapse formation in parallel circuits in vivo. Nature 460:1016-1020. CrossRef Medline

Manookin MB, Weick M, Stafford BK, Demb JB (2010) NMDA receptor contributions to visual contrast coding. Neuron 67:280-293. CrossRef Medline

Morgan JL, Schubert T, Wong RO (2008) Developmental patterning of glutamatergic synapses onto retinal ganglion cells. Neural Dev 3:8. CrossRef Medline

Morgan JL, Soto F, Wong RO, Kerschensteiner D (2011) Development of cell type-specific connectivity patterns of converging excitatory axons in the retina. Neuron 71:1014-1021. CrossRef Medline

Poleg-Polsky A, Diamond JS (2011) Imperfect space clamp permits electrotonic interactions between inhibitory and excitatory synaptic conductances, distorting voltage-clamp recordings. PLoS ONE 6:e19463. CrossRef Medline

Rivlin-Etzion M, Zhou K, Wei W, Elstrott J, Nguyen PL, Barres BA, Huberman AD, Feller MB (2011) Transgenic mice reveal unexpected diversity of on-off direction-selective retinal ganglion cell subtypes and brain structures involved in motion processing. J Neurosci 31:8760-8769. CrossRef Medline

Sagdullaev BT, McCall MA, Lukasiewicz PD (2006) Presynaptic inhibition modulates spillover, creating distinct dynamic response ranges of sensory output. Neuron 50:923-935. CrossRef Medline

Soto F, Bleckert A, Lewis R, Kang Y, Kerschensteiner D, Craig AM, Wong RO (2011) Coordinated increase in inhibitory and excitatory synapses onto retinal ganglion cells during development. Neural Dev 6:31. CrossRef Medline

Soto F, Ma X, Cecil JL, Vo BQ, Culican SM, Kerschensteiner D (2012) Spontaneous activity promotes synapse formation in a cell-type-dependent manner in the developing retina. J Neurosci 32:5426-5439. CrossRef Medline 
Tian N, Copenhagen DR (2001) Visual deprivation alters development of synaptic function in inner retina after eye opening. Neuron 32:439-449. CrossRef Medline

Tovar KR, McGinley MJ, Westbrook GL (2013) Triheteromeric NMDA receptors at hippocampal synapses. J Neurosci 33:9150-9160. CrossRef Medline

Traynelis SF, Wollmuth LP, McBain CJ, Menniti FS, Vance KM, Ogden KK, Hansen KB, Yuan H, Myers SJ, Dingledine R (2010) Glutamate receptor ion channels: structure, regulation, and function. Pharmacol Rev 62:405496. CrossRef Medline

van Wyk M, Wässle H, Taylor WR (2009) Receptive field properties of ONand OFF-ganglion cells in the mouse retina. Vis Neurosci 26:297-308. CrossRef Medline

Wang YV, Weick M, Demb JB (2011) Spectral and temporal sensitivity of cone-mediated responses in mouse retinal ganglion cells. J Neurosci 31: 7670-7681. CrossRef Medline
Watanabe M, Mishina M, Inoue Y (1994) Differential distributions of the NMDA receptor channel subunit mRNAs in the mouse retina. Brain Res 634:328-332. CrossRef Medline

Wei W, Elstrott J, Feller MB (2010) Two-photon targeted recording of GFPexpressing neurons for light responses and live-cell imaging in the mouse retina. Nat Protoc 5:1347-1352. CrossRef Medline

Wong WT, Myhr KL, Miller ED, Wong RO (2000) Developmental changes in the neurotransmitter regulation of correlated spontaneous retinal activity. J Neurosci 20:351-360. Medline

Xu HP, Chen H, Ding Q, Xie ZH, Chen L, Diao L, Wang P, Gan L, Crair MC, Tian N (2010) The immune protein $\mathrm{CD} 3 \zeta$ is required for normal development of neural circuits in the retina. Neuron 65:503-515. CrossRef Medline

Zhang J, Diamond JS (2009) Subunit- and pathway-specific localization of NMDA receptors and scaffolding proteins at ganglion cell synapses in rat retina. J Neurosci 29:4274-4286. CrossRef Medline 